\title{
Antibacterial Effect of Commercial Mouthwashes on Streptococcus mutans: An in vitro study
}

\author{
Efecto Antibacteriano de Colutorios Comerciales en la Proliferación \\ de Streptococcus mutans: Un Estudio in vitro
}

Gonzalo H. Oporto ${ }^{1,3}$; Cynthia Rodríguez-Niklitschek ${ }^{2,4,5}$ \& Priscila Chuhuaicura ${ }^{1,3}$

OPORTO, G. H.; RODRÍGUEZ-NIKLITSCHEK, C. \& CHUHUAICURA, P. Antibacterial effect of commercial mouthwashes on Streptococcus mutans: An in vitro study. Int. J. Odontostomat., 15(4):908-914, 2021.

\begin{abstract}
The aim of this study was to compare the antibacterial effect of eight different commercial (MWs) on two Streptococcus mutans (SM) strains by using the agar well diffusion method. Eight commercial MWs were selected, all of them combined several ingredients in different concentrations, the main active ingredients were: Chlorhexidine gluconate, cetylpyridinium chloride, sodium fluoride, zinc lactate, vitamin B5 and super-oxidized water. The SM strains were extracted from Cultiloops $\circledast$ and incubated for 24 hours at $37^{\circ} \mathrm{C}$. The antimicrobial activity was evaluated using the agar well diffusion method. The inhibition zones were measured using an electronic digital caliper. The R@ software was used to perform the statistical analysis using Kruskall-Wallis test and Dunn's multiple comparisons test. Seven commercial formulas demonstrated inhibitory effect over both SM strains. Only the MW containing super-oxidized water did not exhibit antibacterial activity. Higher inhibitory effect was observed in the chlorhexidine gluconate formula $(27.38 \pm 0.98 \mathrm{~mm}$ and $31.52 \pm 0.64 \mathrm{~mm})$. No statistically significant differences were observed when comparing formulas containing chlorhexidine gluconate in combination with other active ingredients. Seven MWs showed antibacterial activity except super-oxidized water formula. MWs containing chlorhexidine gluconate demonstrated the best effect against SM. However, no statistically significant differences were found when comparing formulas using exclusively chlorhexidine gluconate or combined with other antiseptics. Future research must be performed, focused on developing new MWs with similar antibacterial effects to chlorhexidine, but free of side effects, particularly in long-term treatments
\end{abstract}

KEY WORDS: mouthwash, mouthrinse, chlorhexidine gluconate, Streptococcus mutans, antibacterial, antimicrobial.

\section{INTRODUCTION}

The oral cavity is colonized by a taxonomically complex diversity of microorganisms (i.e. bacteria, fungi, protozoa and archaea) embedded in a matrix of polysaccharide material attached to tooth surfaces known as dental biofilm (Marsh, 2010; Ardizzoni et al., 2018). In a symbiotic environment, the oral microbiota cohabits with the host and has specific metabolic and immunological functions (Marsh). However, the presence of risk factors and diseases may break the equilibrium of the oral ecosystem, leading to a dysbiosis. (Franca et al., 2014; Kilian et al., 2016; Samaranayake \& Matsubara, 2017).

Over the years, different hypotheses regarding dental caries etiology have been investigated (Aas et al., 2008; Fragkou et al., 2017) where studies support that dental biofilm formation has an important role in the development of this disease (Zanela et al., 2002). Frequent sugar exposure leads to modifications in the oral microbiota, providing the environmental conditions

\footnotetext{
${ }^{1}$ Centro de Investigación en Ciencias Odontológicas (CICO), Facultad de Odontología, Universidad de La Frontera, Temuco, Chile.

2 Escuela de Odontología, Facultad de Ciencias, Universidad Mayor, Temuco, Chile.

${ }^{3}$ Departamento de Odontología Integral Adultos, Facultad de Odontología, Universidad de La Frontera, Temuco, Chile.

${ }^{4}$ Escuela de Odontología, Facultad de Odontología, Universidad de La Frontera, Temuco, Chile.

${ }^{5}$ Programa de especialización en Endodoncia, Universidad Mayor, Temuco, Chile.
} 
to induce the dominance of acidogenic/aciduric groups of bacteria such as streptococci, lactobacilli and actinomyces (Aas et al.; Fragkou et al.). The perpetuation of the dysbiosis could cause tooth demineralization and dental caries.

Streptococcus mutans (SM) is a gram positive bacterium and one of the most common pathogens in cariogenic biofilm (Zanela et al.). Previous studies have demonstrated an association between SM and the initial phases of dental caries due to its early colonization of the tooth surface, sugar metabolism and polysaccharide production for bacterial adhesion (Zanela et al.; BaenaMonroy et al., 2005; Marsh). Among the caries preventive approaches, mechanical removal of biofilm is an important intervention to prevent the onset and progression of caries (Okada et al., 2005). However, in susceptible subjects with reported difficulties to perform a proper mechanical removal of dental biofilm, the use of chemotherapeutic agents is beneficial and highly recommended, because these agents can reach difficultto-clean areas (interproximal surfaces) and could reduce the microorganisms growth (Quintas et al., 2015).

Mouthwashes (MWs) are chemical agents that inhibit the growth, colonization and metabolic activity of cariogenic microorganisms and are broadly used as a complementary method controlling dental biofilm (Singh et al., 2013). Among a wide range of active ingredients such as chlorhexidine gluconate (CHX), cetylpyridinium chloride (CPC) and sodium fluoride $(\mathrm{NaF})$ are frequently used in the formulations and may contain different combinations and concentration of ingredients (Anita et al., 2015). Regardless of their components, most of MWs advertisements declare, among their properties, antiseptic effect. However, there are chemotherapeutic agents lacking sufficient scientific evidence to support their antibacterial properties. Based on the exposed antecedents, it is interesting to know the antimicrobial properties of the MWs available on the market. Thus, the purpose of this study was to evaluate the antimicrobial activity of eight commercial MWs against SM

\section{MATERIAL AND METHOD}

The Institutional Ethics Committee of the Universidad de La Frontera approved the study protocol $(075$ 17) used in this research. Procedures were performed following the guidelines of the Clinical and Laboratory Standards Institute (Balouiri et al., 2016).
Bacterial strains and culture conditions. Two SM strains were used in this study (ATCC $₫ 25175$ / ATCC $®$ 35668 Culti-loopsTM ,Thermo Fisher Scientific TM). Bacteria were re-hydrated with $500 \mu \mathrm{L}$ of brain heart infusion broth. Then, $100 \mu \mathrm{L}$ were extracted and deposited in a trypticase soy agar with $5 \%$ sheep blood. The plate was then incubated anaerobically at $37^{\circ} \mathrm{C}$ for $48 \mathrm{~h}$ using the BD GaspPakTM EZ container system. The colonies obtained were transferred to a tube containing tryptic soy broth and adjusted to 0.5 McFarland turbidity standard (equivalent to $1.5 \times 108$ CFU / mL) (Shafiee et al., 2016).

Selected Mouthwashes. Eight commercial MWs were selected and coded according to their active ingredients. Seven of them combined several ingredients in different concentrations (Table I): four MWs had $\mathrm{CHX}$, five contained $\mathrm{CPC}$, three contained $\mathrm{NaF}$, two had zinc lactate (ZL) and one contained superoxidized water (SOW). Physiological saline solution was the negative control (NC).

Inhibition zone test. Antibacterial activity was assessed using the agar well diffusion method (Singh et al.). An inoculum of the tested microorganism adjusted to $0.5 \mathrm{McF}$ arland turbidity standard was streaked over Müeller-Hinton agar plates with sterile laboratory swabs. Then, four equidistant wells with a diameter of $9.2 \mathrm{~mm}$ were made aseptically. Afterwards, a volume of $130 \mu \mathrm{L}$ of each MW (Table I) was deposited into the well and incubated for $48 \mathrm{~h}$ at $37^{\circ} \mathrm{C}$ in an anaerobic environment (Fig. 1). This procedure was
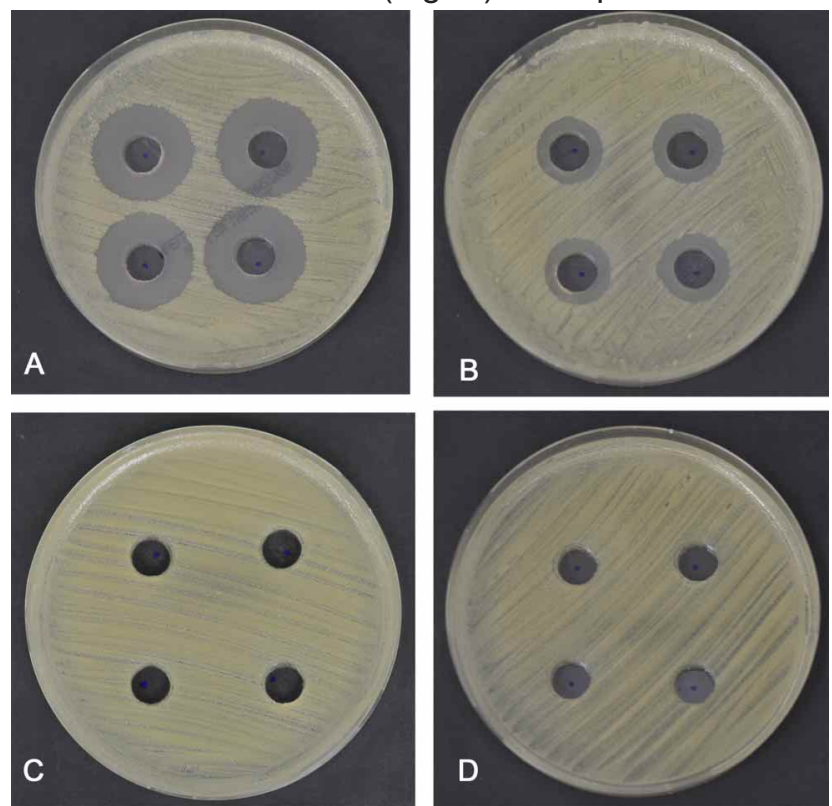

Fig. 1. Inhibition zones observed in agar plaques tested.A) $\mathrm{CHX}$ B) CPCNaF (a) C) SOW/NaCl D) NC. 
Table I. Chemical composition of mouthwashes (MWs) tested.

\begin{tabular}{|c|c|c|}
\hline MW Code & Compounds (Formula) & Concentration (\%) \\
\hline \multirow[t]{2}{*}{$\mathrm{CHX}$} & Chlorhexidine gluconate & 0.12 \\
\hline & Chlorhexidine gluconate & 0.12 \\
\hline \multirow[t]{3}{*}{$\mathrm{CHX} / \mathrm{NaF}$} & - $\quad$ SodiumFluoride $(\mathrm{NaF})$ & 0.05 \\
\hline & Sodium saccharin & 0.06 \\
\hline & - Chlorhexidine gluconate & 0.05 \\
\hline \multirow[t]{2}{*}{$\mathrm{CHX/CPC/ZL}$} & - $\quad$ Cetylpyridinium chloride (CPC) & 0.05 \\
\hline & _ $\quad$ Zinc lactate $(\mathrm{ZL})$ & 0.14 \\
\hline \multirow{3}{*}{$\mathrm{CHX/CPC}$} & _ Chlorhexidine gluconate & 0.12 \\
\hline & _ $\quad$ Cetylpyridinium chloride & 0.05 \\
\hline & _ $\quad$ Vitamin B5 (Panthenol) (VB5) & 0.50 \\
\hline \multirow{3}{*}{ VB5/CPC/ZL } & _ Cetylpyridinium chloride & 0.05 \\
\hline & _ Zinc lactate & 0.14 \\
\hline & _ $\quad$ Permethol & 0.10 \\
\hline \multirow{2}{*}{$\mathrm{CPC} / \mathrm{NaF}(\mathrm{a})$} & _ Cetylpyridinium chloride & 0.075 \\
\hline & _ SodiumFluoride & 0.05 \\
\hline \multirow{3}{*}{$\mathrm{CPC} / \mathrm{NaF}(\mathrm{b})$} & _ $\quad$ Cetylpyridinium chloride & 0.05 \\
\hline & - $\quad$ SodiumFluoride & 0.05 \\
\hline & _ $\quad$ Super-oxidized water (SOW) $(100 \mathrm{~mL})$ & - \\
\hline \multirow{3}{*}{$\mathrm{SOW} / \mathrm{NaCl}$} & - $\quad$ Sodium chloride $(\mathrm{NaCl})>1 \mathrm{mg}$ & 0.001 \\
\hline & _ $\quad$ Hypochlorous acid $(\mathrm{HOCl})>0.8 \mathrm{mg}$ & 0.0008 \\
\hline & _ Sodium hypochlorite $(\mathrm{NaOCl})>0.2 \mathrm{mg}$ & 0.0002 \\
\hline NC & _ Physiological saline solution & 0.9 \\
\hline
\end{tabular}

$\mathrm{NC}=$ Negative Control

performed in duplicate. Inhibition zones were measured in millimeters using an electronic digital caliper (RedLine ${ }^{\circledR}$ Tools, Plymouth, MN, USA).

Statistical analysis. The statistics software R (R Core Team, Vienna, Austria) was used for the statistical analysis, using the Kruskal-Wallis test and Dunn's multiple comparisons test (post hoc). p-values less than 0.05 were considered statistically significant.

\section{RESULTS}

Tested MWs exhibited an inhibitory effect over SM except SOW/NaCl (Table II). In fact, no statistically significant differences were found between SOW/NaCl and NC. In both SM strains, significant differences $(p<$ 0.0001) were observed between $\mathrm{CHX}$ and $\mathrm{CPC} / \mathrm{NaF}$ (a) as well as when comparing the inhibition zones of $\mathrm{CHX}$ vs. SOW/NaCl and $\mathrm{CHX} / \mathrm{CPC} / \mathrm{ZL}$ vs. SOW/NaCl. No significant differences were observed among $\mathrm{CHX} / \mathrm{NaF}$, $\mathrm{CHX}, \mathrm{CHX} / \mathrm{CPC}$ and $\mathrm{CHX} / \mathrm{CPC} / \mathrm{ZL}$. The largest inhibition zone was found when using CHX in SM ATCC 35668 plates (Fig. 2), which was slightly higher than CHX/CPC, although no significant differences were found. Nevertheless, differences were detected when comparing CHX vs. vitamin B5 (VB5)-CPC-ZL $(p<0.0001)$.

\section{DISCUSSION}

Today practitioners and patients have a wide array of MWs with different active ingredients and concentrations. Among them, $\mathrm{CHX}$ is considered the gold standard due to its proven antibacterial efficacy (Tang et al., 2015). Its cationic nature is included among the molecular $\mathrm{CHX}$ properties, which allows binding to the bacterial wall. Moreover, depending on the therapeutic indication, $\mathrm{CHX}$ MWs could be used at different concentrations as a bacteriostatic or bactericidal agent (Gunsolley, 2006). The results of this research showed that larger inhibition zones were found in MWs containing $\mathrm{CHX}$ as the active ingredient, even combined with other compounds such as CPC, $\mathrm{NaF}$ or ZL. These results support previous reports regarding its efficacy (Coelho et al., 2017). However, side effects such as tooth discoloration, alteration in taste perception and oral mucosal erosion have been reported, especially in its long-term use (Tsourounakis et al., 2013; Coelho et al.). Thus, patients should avoid using it as a MW for longer than four weeks. Some in vitro studies also reported that may be potentially toxic to the host's cells (de Oliveira et al., 2018).

$\mathrm{CPC}$ is a quaternary ammonium compound with broad-spectrum antibacterial activity, which disrupts the 
Table II. Streptococcus mutans (SM) strains - mean values of inhibition zones in millimeters (mm) and statistical difference.

\begin{tabular}{|c|c|c|c|c|}
\hline MW & SM & Statistical difference & SM & Statistical difference \\
\hline Code & ATCC 25175 & $(p<0.0001)$ & ATCC 35668 & $(p<0.0001)$ \\
\hline $\mathrm{CHX/NaF}$ & $24.50 \pm 1.19$ & $\begin{array}{ll} & \mathrm{SOW} / \mathrm{NaCl} \\
- & \mathrm{NC}\end{array}$ & $25.36 \pm 0.55$ & $\begin{array}{ll} & \mathrm{SOW} / \mathrm{NaCl} \\
- & \mathrm{NC}\end{array}$ \\
\hline $\mathrm{CHX}$ & $27.38 \pm 0.98$ & $\begin{array}{ll}- & \mathrm{CPC} / \mathrm{NaF}(\mathrm{a}) \\
- & \mathrm{SOW} / \mathrm{NaCl} \\
- & \mathrm{NC}\end{array}$ & $31.52 \pm 0.64$ & $\begin{array}{ll}- & \text { VB5_CPC_ZL } \\
- & \text { CPC/NaF (a) } \\
- & \text { SOW/NaCl } \\
- & \text { NC }\end{array}$ \\
\hline $\mathrm{CHX/CPC/ZL}$ & $23.13 \pm 0.64$ & $\begin{array}{ll} & \mathrm{SOW} / \mathrm{NaCl} \\
- & \mathrm{NC}\end{array}$ & $24.93 \pm 1.07$ & $\begin{array}{ll}- & \mathrm{SOW} / \mathrm{NaCl} \\
- & \mathrm{NC}\end{array}$ \\
\hline $\mathrm{CHX/CPC}$ & $27.38 \pm 0.91$ & $\begin{array}{ll}- & \mathrm{CPC} / \mathrm{NaF}(\mathrm{a}) \\
- & \mathrm{SOW} / \mathrm{NaCl} \\
& \mathrm{NC}\end{array}$ & $30.31 \pm 1,01$ & $\begin{array}{ll}- & \mathrm{CPC} / \mathrm{NaF}(\mathrm{a}) \\
- & \mathrm{SOW} / \mathrm{NaCl} \\
& \mathrm{NC}\end{array}$ \\
\hline VB5/CPC/ZL & $18.25 \pm 0.88$ & & $16.27 \pm 0.55$ & \\
\hline $\mathrm{CPC} / \mathrm{NaF}(\mathrm{a})$ & $16.50 \pm 0.53$ & & $15.29 \pm 0.30$ & \\
\hline $\mathrm{CPC} / \mathrm{NaF}(\mathrm{b})$ & $18.38 \pm 0.91$ & & $16.52 \pm 0.35$ & \\
\hline SOW/NaCl & 9.2 & & 9.2 & \\
\hline NC & 9.2 & & 9.2 & \\
\hline
\end{tabular}

$\mathrm{CHX}=$ Chlorhexidine gluconate, $\mathrm{CHX} / \mathrm{NaF}=$ Chlorhexidine gluconate + sodium fluoride, $\mathrm{CHX} / \mathrm{CPC}=\mathrm{Chlorhexidine} \mathrm{gluconate}+$ cetylpyridinium chloride, $\mathrm{CHX/CPC/ZL}=$ Chlorhexidine gluconate + cetylpyridinium chloride + zinc lactate, $\mathrm{VB} 5 / \mathrm{CPC} / \mathrm{ZL}=\mathrm{Vitamin} \mathrm{B} 5(\mathrm{Panthenol})+$ cetylpyridinium chloride + zinc lactate, $\mathrm{CPC} / \mathrm{NaF}(\mathrm{a})=$ Cetylpyridinium chloride $(0.075 \%)+$ sodium fluoride $\mathrm{CPC} / \mathrm{NaF}(\mathrm{b})=\mathrm{Cetylpyridinium}$ chloride $(0.05 \%)+$ sodium fluoride SOW/NaCl= Super-oxidided water + sodium chloride. NC=Negative Control

\section{Streptococcus mutans (ATCC 25175)}

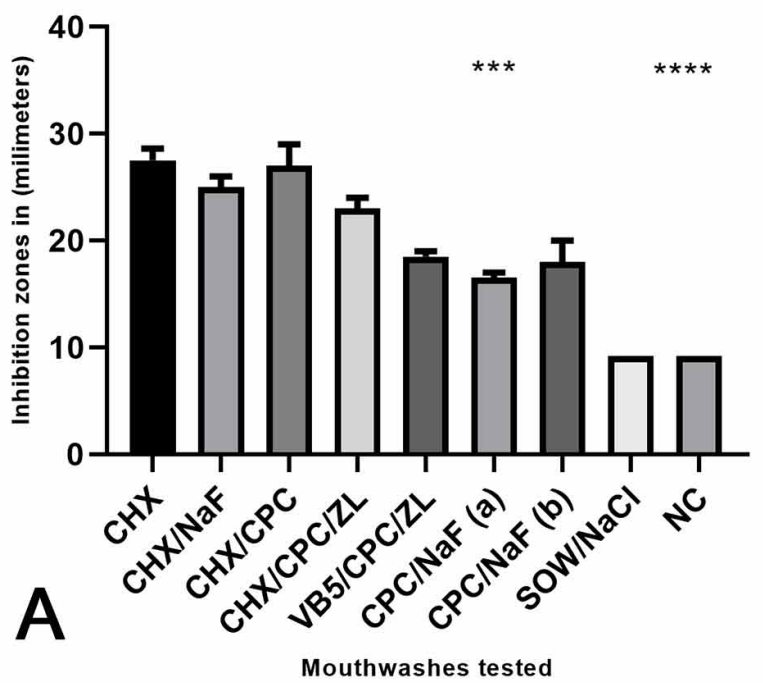

Streptococcus mutans (ATCC 35668)

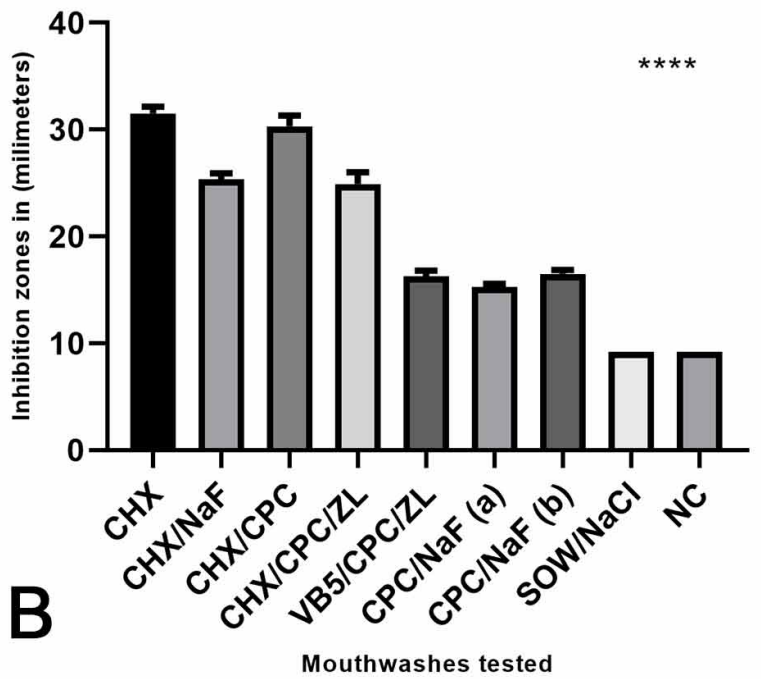

Fig. 2. Inhibition zones (measured in millimeters) in both Streptococcus mutans (SM) strains. A) SM ATCC 25175 B) SM ATCC $® 35668$.

permeability of the cell membrane, inducing leakage of intracellular components until cell death (Watanabe et al., 2015). Yang et al. (2015) evaluated the effect of commercial MWs on the reduction of SM colonies, and a significant antibacterial activity of CPC $0.05 \%$ was determined. Other studies havereported that short-term treatments with various concentrations of CPC $(0.025$ $\%-0.1 \%$ ) could reduce the cariogenic biofilm accumulation, especially in the early stages of SM biofilm formation. However, when comparing the antimicrobial effect of $\mathrm{CHX} 0.2 \%$ and $\mathrm{CPC} 0.05 \%$ in mature SM biofilm, it was found that $\mathrm{CHX}$ was more effective at reducing the colony forming units of SM (Pandit et al., 2015). Five MWs formulas containing CPC were tested, including concentrations between $0.075 \%$ and $0.05 \%$. The best performance of CPC 
was detected when it was used in combination with $\mathrm{CHX}$ (inhibition zones were $27.38 \pm 0.9 \mathrm{~mm}$ over ATCC $₫ 25175$ and $30.31 \pm 1.01 \mathrm{~mm}$ over ATCC $₫$ 35668) in both SM strains. Furthermore, CHX/CPC also showed better results $(27.38 \pm 0.91$ and $30.31 \pm 1.01)$ than $\mathrm{CPC} / \mathrm{NaF}$ (a) $(16.50 \pm 0.53$ and $15.29 \pm 0.30)$, an effect which may be attributed to differences in their composition ( $\mathrm{CHX}$ effect). The meta-analysis carried out by Gunsolley found a significant antiplaque effect of $\mathrm{CHX} 0.12 \%$. However, products containing a varied concentration of CPC (4.5-7\%) showed inconsistent results and significant heterogeneity among studies (Gunsolley).

Fluoride MWs have been used in preventive treatments against dental caries in children for decades and their effectiveness has been extensively investigated and proven (Ripa, 1991; Marinho et al., 2016). NaF is the most common fluoride salt, and it is combined with $\mathrm{CHX}$ or $\mathrm{CPC}$ to improve its antibacterial activity. However, results on this issue are inconclusive. Latimer et al. (2015) compared the effect of CPC 0.075 $\%$ and CPC $0.075 \%$ combined with NaF. In this study, no influence was identified on the antibacterial and antibiofilm potency of CPC containing NaF. On the other hand, Yang et al. observed significant antibacterial effects in MWs formulas that combined $0.02 \% \mathrm{NaF}$ and $0.05 \%$ CPC. In our study, three MWs containing $\mathrm{NaF} 0.05 \%$ were included, and even though differences in inhibition zones were observed (higher for $\mathrm{CHX} / \mathrm{NaF}$ and lowest for $\mathrm{CPC} / \mathrm{NaF}$ (a), Table II), these differences were not statistically significant in the antibacterial effect.

ZL has been used in oral hygiene products due to its antimicrobial activity and for reducing volatile sulfur compounds that could be associated with halitosis. Srisilapanan et al. (2019) compared the effect of $0.14 \%$ of ZL against a placebo to reduce oral malodor. The results suggest that zinc salts have a potential effect in reducing malodor (Srisilapanan et al.). Yet the scientific literature is inconclusive regarding the longterm effect of these products on oral halitosis (Roldán et al., 2003). In our study, two MWs containing ZL were compared (VB5/CPC/ZL and CHX/CPC/ZL); however, no statistical significance were exhibited between them in their antibacterial effect.

Reactive species such as SOW have also been studied for antimicrobial activity. It is obtained by exposing sodium chloride $(\mathrm{NaCl})$ through a semipermeable membrane and finally, producing oxychlorine ions using electrolysis. The formula SOW/
$\mathrm{NaCl}$ is defined as a broad spectrum antimicrobial that denatures the microbial wall proteins with no harm to human cells (Yahagi et al., 2000). The use of SOW is indicated in infectious disease treatment, including skin abnormalities or ulcers, and may be associated with the wound healing process (Yahagi et al.). In dentistry, it has been used in endodontics, for root canal irrigation (Shimizu et al., 1994), in periodontics, for irrigation of the gingival pocket and in treatment of oropharyngeal lesions (Hata et al., 1996). According to our results, the formula SOW/NaCl was the only MW tested that did not exhibit any antibacterial effect against SM. In fact, no statistical difference was found when comparing SOW/NaCl and negative control (NC) of saline solution in the two SM strains. Some studies have described the antimicrobial properties of electrolyzed water as fluctuating depending on the oxidation-reduction potential, $\mathrm{pH}$ solution (neutral, acidic or alkaline) and chlorine concentration (Len et al., 2000; Landa-Solis et al., 2005). This background may explain the variability in the behavior of the SOW, especially in the antibacterial effect on oral bacteria. Although this in vitro study has limitations, the results support that $\mathrm{CHX}$ had the best antibacterial effect alone or in combination to other active ingredients. However, clinical studies are needed to determine its effect in oral biofilm.

\section{CONCLUSION}

According to the results, only the MW based on SOW/NaCl did not show any antibacterial effect, whereas the formulas containing $\mathrm{CHX}$ had the strongest effect. Interestingly, no statistically significant differences were found when comparing MWs using exclusively $\mathrm{CHX}$ orCHX combined with other antiseptics. To date, $\mathrm{CHX}$ remains the most effective chemotherapeutic agent used against SM, but still remains unknown the effect of its long-term use in microbial cells and oral tissues. Thus, an alternative MW with similar antibacterial effect but with no side effects is needed, particularly for use in long-term therapies.

\section{ACKNOWLEDGMENTS}

PC would like to thank the National Agency for Research and Development (ANID) / Scholarship Program / BECA MAGISTER NACIONAL/201822182175 . Also, this study was partially supported by 
the Dirección de Investigación (DIUFRO), Universidad de La Frontera, Temuco, Chile (DI19-0040, DI17-0101 and DI20-0152) and the Dirección de Investigación y Creación Artística, Universidad Mayor, Chile (Fondo Start Up-2017 (OI-101166)).

OPORTO, G. H.; RODRÍGUEZ-NIKLITSCHEK, C. \& CHUHUAICURA, P. Efecto antibacteriano de colutorios comerciales en la proliferación de Streptococcus mutans: Un estudio in vitro. Int. J. Odontostomat., 15(4):908-914, 2021.

RESUMEN: El objetivo de este estudio fue comparar el efecto antibacteriano de ocho colutorios comerciales en la proliferación de dos cepas de Streptococcus mutans (SM) mediante el método de difusión de pozos de agar. Se seleccionaron ocho colutorios comerciales, todos ellos combinados con varios ingredientes en diferentes concentraciones, los principales ingredientes activos fueron: gluconato de clorhexidina, cloruro de cetilpiridinio, fluoruro de sodio, lactato de zinc, vitamina B5 y agua superoxidada. Las cepas SM se extrajeron de Cultiloops $₫$ y se incubaron durante 24 horas a $37^{\circ} \mathrm{C}$. La actividad antimicrobiana se evaluó mediante el método de difusión de placa de agar. Las zonas de inhibición se midieron utilizando un calibre digital electrónico. Se utilizó el software $\mathrm{R}$ @ ) para realizar el análisis estadístico mediante la prueba de Kruskall-Wallis y la prueba de comparaciones múltiples de Dunn. Siete fórmulas comerciales demostraron efecto inhibidor sobre ambas cepas SM. Solo el colutorio que contenía agua superoxidada no mostró actividad antibacteriana. Se observó un mayor efecto inhibidor en las fórmulas congluconato de clorhexidina $(27,38 \pm 0,98$ $\mathrm{mm}$ y $31,52 \pm 0,64 \mathrm{~mm})$. No se observaron diferencias estadísticamente significativas al comparar fórmulas que contienen gluconato de clorhexidina en combinación con otros ingredientes activos. Siete MW mostraron actividad antibacteriana excepto la fórmula de agua superoxidada. Los colutorios que contienen gluconato de clorhexidina mostraron el mejor efecto contra SM. Sin embargo, no se encontraron diferencias estadísticamente significativas al comparar fórmulas que combinaron con otros principios activos. Se deben realizar investigaciones, enfocadas en el desarrollo de nuevos colutorios con efectos antibacterianos similares a la clorhexidina, pero libres de efectos secundarios, particularmente en tratamientos a largo plazo.

PALABRAS CLAVE: enjuague bucal, enjuague bucal, gluconato de clorhexidina, Streptococcus mutans, antibacteriano, antimicrobiano.

\section{REFERENCES}

Aas, J. A.; Griffen, A. L.; Dardis, S. R.; Lee, A. M.; Olsen, I.; Dewhirst, F. E.; Leys, E. J. \& Paster, B. J. Bacteria of dental caries in primary and permanent teeth in children and young adults. J. Clin. Microbiol., 46(4):1407-17, 2008.
Anita, P.; Balan, I.; Ethiraj, S.; Madan Kumar, P. D.; Balan, I. N. \& Ethiraj, S. In vitro antibacterial activity of Camellia sinensis extract against cariogenic microorganisms. J. Basic Clin. Pharm., 6(1):35-9, 2015.

Ardizzoni, A.; Pericolini, E.; Paulone, S.; Orsi, C. F.; Castagnoli, A.; Oliva, I.; Strozzi, E. \& Blasi, E. In vitro effects of commercial mouthwashes on several virulence traits of Candida albicans, Viridans streptococci and Enterococcus faecalis colonizing the oral cavity. PLoS One, 13(11):e0207262, 2018.

Baena-Monroy, T.; Moreno-Maldonado, V.; Franco-Martínez, F.; Aldape-Barrios, B.; Quindós, G. \& Sánchez-Vargas, L. O. Candida albicans, Staphylococcus aureus and Streptococcus mutans colonization in patients wearing dental prostheses. Med. Oral Patol. Oral Cir. Bucal, 10 Suppl. 1:E27-39, 2005.

Balouiri, M.; Sadiki, M. \& Ibnsouda, S. K. Methods for in vitro evaluating antimicrobial activity: A review. J. Pharm. Anal., 6(2):71-9, 2016.

Coelho, A. S. E. C.; Paula, A. B. P.; Carrilho, T. M. P.; da Silva, M. J. R. F.; Botelho, M. F. R. R. \& Carrilho, E. V. V. F. Chlorhexidine mouthwash as an anticaries agent: A systematic review. Quintessence Int., 48(7):585-91, 2017.

de Oliveira, J. R.; Belato, K. K.; de Oliveira, F. E.; Jorge, A. O. C.; Camargo, S. E. A. \& de Oliveira, L. D. Mouthwashes: an in vitro study of their action on microbial biofilms and cytotoxicity to gingival fibroblasts. Gen. Dent., 66(2):28-34, 2018.

Fragkou, S.; Balasouli, C.; Tsuzukibashi, O.; Argyropoulou, A.; Menexes, G.; Kotsanos, N. \& Kalfas, S. Streptococcus mutans, Streptococcus sobrinus and Candida albicans in oral samples from caries-free and caries-active children. Eur. Arch. Paediatr. Dent., 17(5):367-75, 2017

Franca, J. R.; De Luca, M. P.; Ribeiro, T. G.; Castilho, R. O.; Moreira, A. N.; Santos, V. R. \& Faraco, A. A. G. Propolis--based chitosan varnish: drug delivery, controlled release and antimicrobial activity against oral pathogen bacteria. BMC Complement. Altern. Med., 14:478, 2014.

Gunsolley, J. C. A meta-analysis of six-month studies of antiplaque and antigingivitis agents. J. Am. Dent. Assoc., 137(12):1649-57, 2006.

Hata, G.; Uemura, M.; Weine, F. S. \& Toda, T. Removal of smear layer in the root canal using oxidative potential water. J. Endod., 22(12):643-5, 1996.

Kilian, M.; Chapple, I. L. C.; Hannig, M.; Marsh, P. D.; Meuric, V.; Pedersen, A. M. L.; Tonetti, M. S.; Wade, W. G. \& Zaura, E. The oral microbiome - an update for oral healthcare professionals. Br. Dent. J., 221(10):657-66, 2016.

Landa-Solis, C.; González-Espinosa, D.; Guzmán-Soriano, B.; Snyder, M.; Reyes-Terán, G.; Torres, K. \& Gutierrez, A. A. Microcyntm: a novel super-oxidized water with neutral $\mathrm{pH}$ and disinfectant activity. J. Hosp. Infect., 61:291-9, 2005.

Latimer, J.; Munday, J. L.; Buzza, K. M.; Forbes, S.; Sreenivasan, P. K. \& McBain, A. J. Antibacterial and anti-biofilm activity of mouthrinses containing cetylpyridinium chloride and sodium fluoride. BMC Microbiol., 15:169, 2015.

Len, S. V.; Hung, Y. C.; Erickson, M. \& Kim, C. Ultraviolet spectrophotometric characterization and bactericidal properties of electrolyzed oxidizing water as influenced by amperage and pH. J. Food Prot., 63(11):1534-7, 2000.

Marinho, V.; Chong, L.; Worthington, H. \& Walsh, T. Fluoride mouthrinses for preventing dental caries in children and adolescents. Cochrane Database Syst. Rev., 7(7):CD002284, 2016.

Marsh, P. D. Microbiology of dental plaque biofilms and their role in oral health and caries. Dent. Clin. North. Am., 54(3):441-54, 2010.

Okada, M.; Soda, Y.; Hayashi, F.; Doi, T.; Suzuki, J.; Miura, K. \& Kozai, K. Longitudinal study of dental caries incidence associated with Streptococcus mutans and Streptococcus sobrinus in preschool children. J. Med. Microbiol., 54(Pt. 7):661-5, 2005. 
Pandit, S.; Cai, J. N.; Jung, J. E.; Lee, Y. S. \& Jeon, J. G. Effect of brief cetylpyridinium chloride treatments during early and mature cariogenic biofilm formation. Oral Dis., 21(5):565-71, 2015.

Quintas, V.; Prada-López, I.; Donos, N.; Suárez-Quintanilla, D. \& Tomás, I. In situ neutralisation of the antibacterial effect of $0.2 \%$ Chlorhexidine on salivary microbiota: Quantification of substantivity. Arch. Oral Biol., 60(8):1109-16, 2015.

Ripa, L. W. A critique of topical fluoride methods (dentifrices, mouthrinses, operator-, and self-applied gels) in an era of decreased caries and increased fluorosis prevalence. J. Public Health Dent., 51(1):23-41, 1991

Roldán, S.; Winkel, E. G.; Herrera, D.; Sanz, M. \& Van Winkelhoff, A. J. The effects of a new mouthrinse containing chlorhexidine, cetylpyridinium chloride and zinc lactate on the microflora of oral halitosis patients: a dual-centre, double-blind placebo-controlled study. J. Clin. Periodontol., 30(5):427-34, 2003.

Samaranayake, L. \& Matsubara, V. H. Normal oral flora and the oral ecosystem. Dent. Clin. North Am., 61(2):199-215, 2017.

Shafiee, F.; Moghadamnia, A. A.; Shahandeh, Z.; Sadighian, F. \& Khodadadi, E. Evaluation of the antibacterial effects of aqueous and ethanolic leaf extracts of Aloysia citriodora ( Lemon verbena) on Streptococcus mutans and Streptococcus sobrinus. Electron. Physician, 8(12):3363-8, 2016.

Shimizu, Y.; Furusawa, T.; Mizunuma, K.; Endo, M.; Nishikata, T. \& Inada, T. Disinfectant action of electrolyzed oxidizing water to dental instruments and finger. J. Dent. Med., 40:905-11, 1994.

Singh, A.; Daing, A. \& Dixit, J. The effect of herbal, essential oil and chlorhexidine mouthrinse on de novo plaque formation. Int. J. Dent. Hyg., 11:48-52, 2013.

Srisilapanan, P.; Roseman, J. \& Likitsatian, T. Clinical effect of toothpaste and mouth rinse containing zinc lactate on oral malodor reduction. J. Clin. Exp. Dent., 11:346-52, 2019.

Tang, X.; Sensat, M. \& Stoltenberg, J. The antimicrobial effect of chlorhexidine varnish on mutans streptococciin patients with fixed orthodontic appliances: a systematic review of clinical efficacy. Int. J. Dent. Hyg., 14:53-61, 2015.

Tsourounakis, I.; Palaiologou-Gallis, A.; Stoute, D.; Maney, P. \& Lallier, T. Effect of Essential Oil and Chlorhexidine Mouthwashes on Gingival Fibroblast Survival and Migration. J. Periodontol., 84(8):1211-20, 2013

Watanabe, E.; Nascimento, A. P.; Guerreiro-Tanomaru, J. M.; Razaboni, A. M.; de Andrade, D. \& Tanomaru-Filho, M. Antiseptic mouthwashes: in vitro antibacterial activity. Acta. Odontol. Latinoam., 28(2):180-4, 2015.

Yahagi, N.; Kono, M.; Kitahara, M.; Ohmura, A.; Sumita, O.; Hashimoto, T.; Hori, K.; Ning-Juan, C.; Woodson, P.; Kubota, S.; et al. Effect of electrolyzed water on wound healing. Artif. Organs, 24(12):984-7, 2000

Yang, S. J.; Han, S. H.; Lee, A. R.; Jun, J. H.; Son, M. W.; Oh, S. H.; Kim, J. \& Paik, S. Y. Evaluation of antimicrobial effects of commercial mouthwashes utilized in South Korea. BMB Rep., 48(1):42-7, 2015.

Zanela, N.; Bijella, M. \& Rosa, O. The influence of mouthrinses with antimicrobial solutions on the inhibition of dental plaque and on the levels of mutans streptococci in children. Pesqui. Odontol. Bras., 16:101-6, 2002.
Corresponding author:

Mg. Priscila Chuhuaicura

Departamento de Odontología Integral Adultos

Facultad de Odontología

Universidad de La Frontera

Francisco Salazar 01145

Temuco

CHILE

E-mail: priscila.chuhuaicura@ufrontera.cl 